\title{
CHRISTIANITY AS PUBLIC RELIGION IN THE POST-SECULAR 21ST
}

\section{CENTURY}

Tom Gibbons

Summary

Keywords

The Christian Gospel as Public

Secularization and the Privatization of Religion

The Global Growth of Christianity in the Face of Secularization

Historiography

Primary Sources

Further Reading

References

\section{Summary}

The Christian gospel message was intended to be public. The biblical basis for this is undisputable. Yet in recent times the visibility of the Christian perspective on issues affecting society that are often debated in the public sphere has declined in many Western societies. In "Sociology and Theology Reconsidered: Religious Sociology and the Sociology of Religion in Britain," John Brewer states that "religion has tended to be restricted to the private sphere" in many modern nation-states over the 20th century, meaning public displays of religiosity have been frowned upon and strictly limited. The privatization of religion is a result of a decline in the importance of religion in modern societies, a process termed "secularization". Yet, the idea of increasing secularization in society is not accepted by all. Despite commonsense notions that such societies have become increasingly secular in nature, Christian values do still clearly underpin the nature and functioning of institutions of the state and government in many western nation-states. Bryan Turner states in "Religion and Contemporary Sociological Theories" that since the late 20th century at least, there has actually been a "growing recognition of the importance of religion in public life," something José Casanova termed "public religion". The sociologist Peter Berger suggested that we began to witness the 
"desecularization" of the world in the late 20th century as there has been (and continues to be) a global resurgence in religious adherents. This situation was evident most considerably in the rapid growth of Christianity across the globe throughout the 20th century, a phenomenon that continues to gather momentum into the 21 st century.

\section{Keywords}

Christianity; Religion; Public Religion; Public Sphere; Secular

\section{The Christian Gospel as Public}

From its inception, Christianity has always been and remains focused on the public declaration of the gospel of Jesus Christ. The term 'gospel' means 'good news' and the Christian message is that Jesus Christ came to save the world from sin which is leading humanity towards eternal damnation. Before Jesus started his ministry recorded in the four gospels, John the Baptist publicly declared that Jesus would come and called people to repent of their sins (Matthew 3: 1-11; Mark 1:1-8; Luke 3:1-18; John 1:29-34). John baptized Jesus in the Jordan River and Jesus was anointed by the Holy Spirit (Matthew 3:13-17; Mark 1:911; Luke 3:21-22; John 1:32-34) who subsequently led him into the desert to be tempted by the devil (Matthew 4:1-11; Mark 1:12-13; Luke 4:1-13). When Jesus emerged from the desert after forty days and forty nights, he immediately began to preach (Matthew 4:12-17; Mark 1:14-15; Luke 4:14-28) and his three years of public ministry began leading towards his arrest, trial, crucifixion, death and burial (Matthew 26:47-27:66; Mark 14:43-15:47; Luke 22:47-23:56; John 18-19), prior to his resurrection and ascension to heaven (Matthew 28; Mark 16; Luke 24; John 20-21). During his ministry Jesus spoke in parables (stories) using illustrations from daily life to explain the meaning of his teaching. Jesus often taught on the 
importance of his followers putting what he taught into practice so as to be seen by others. For instance Jesus said:

You are the light of the world. A town built on a hill cannot be hidden. Neither do people light a lamp and put it under a bowl. Instead they put it on its stand, and it gives light to everyone in the house. In the same way, let your light shine before others, that they may see your good deeds and glorify your Father in heaven. (Matthew 5:14-16)

Jesus promised to send the Holy Spirit to his disciples after he had ascended to heaven (Luke 24:49; John 14:26; 15:26). Following his ascension, 120 of Jesus' followers were praying in an upper room in a building in central Jerusalem when the Holy Spirit came and anointed them (Acts 1:12-2:13). Peter emerged from the upper room full of the Holy Spirit and preached about Jesus and about 3000 people became believers that day (Acts 1:14-41). The book of Acts is full of examples of these early Christians proclaiming the gospel of Jesus and being persecuted and even martyred for such public declarations - for example, see the story of Stephen, the first Christian martyr (Acts 6:8-7:59). Saul, who was well known for persecuting Christians with the full backing of the Jewish authorities, was miraculously converted after encountering Jesus in a vision on the road to Damascus where he was going to find Christians to bring back to Jerusalem as prisoners. After his miraculous conversion, he immediately began to preach the gospel of Jesus Christ in Damascus (Acts 9:1-31). His name was later changed from Saul to Paul and he began a travelling ministry involving the preaching of the gospel in towns and cities across what is now the Middle East and parts of Europe. This led to the establishment of the first Christian churches. 
Clearly the Christian gospel message was originally intended to be declared publicly and this has been the case to varying degrees over the last 2000 years. Yet in recent times many argue that it has been pushed behind the scenes of public life along with other public displays of religiosity due to the onset of modernity leading to postmodernity and the secularization that is said to have accompanied them.

\section{Secularization and the Privatization of Religion}

The term 'secularization' refers to a process whereby identifications with religious values and institutions decline and become replaced by irreligious values and secular institutions in a particular society. At least to some extent, this occurred in Western societies following the $17^{\text {th }}$ century Enlightenment period or scientific revolution which resulted in what are known as the modernizing revolutions of the $18^{\text {th }}$ and $19^{\text {th }}$ centuries, including the American and French political revolutions and the British Industrial Revolution which was inherently economic in nature.

Fraser and Campolo (1992: 192) state that the onset of modernization, industrialization and secularization brought huge changes to the established "Great Chain of Being" that previously existed across what are now European nation-states. Prior to the Middle Ages for hundreds of years Christianity and the established churches were central and influential in all public affairs. In pre-modern Europe the established hierarchy was comprised of God at the top followed by human beings, nature and inanimate objects in order below (Fraser and Campolo, 1992: xiv). The onset of modernization in the eighteenth century involving the rise of modern industry, urbanisation and reliance upon machinery based upon scientific reasoning, corroded the links in the great chain of being. One of the many consequences of modernity was that faith in God was challenged and a new faith in secular civilization was birthed. Whilst this did not render faith in God obsolete by any means, and 
Christian values continued to underpin the nature and functioning of institutions of the state and government, according to Mouzelis (2012: 209) "the idea that modernity is in the longterm incompatible with religion has a long history". In response to modernization, from the latter part of the nineteenth century the secularization thesis was theorized by what are now considered to be classical social theorists and founders of the social science disciplines. These founding fathers included: Auguste Comte, Karl Marx, Max Weber and Émile Durkheim. These classical social theorists have also been described as 'secularists', yet it might be more accurate to call them 'theorists of secularization'. Bryan Wilson (1998: 46) notes a sharp distinction must be made between the two. He defines secularization theory as a group of neutral propositions that seek to focus upon distinct social processes; whereas secularism is the ideology that aims for the removal of religion from social affairs.

Grace Davie (2015: 186) clarifies the various terms associated with secularization in the following neat summary:

'Secular' is normally used as an adjective to describe a condition or situation, noting that its meaning is not only imprecise (hovering between neutrality and hostility), but slips easily between the descriptive and normative - the notion of a secular state, for example, can be used in either sense. 'Secularization' is quite different: it is a process, which takes place differently in different societies and encompasses a multiplicity of factors not all of which move in the same direction. Societies that demonstrate a marked decline in religious activity over a given period of time may or may not be associated with secular institutions and vice versa. 'Secularity' is less frequently used in popular parlance but denotes a state of affairs which is described as secular; by and large it is a neutral term. 'Secularism' in contrast is an ideology and implies commitment - to the process of secularization, for instance, or to the affirmation of the secular in this or that sphere of society. 
The core concerns of the secularization thesis include religion losing claims to authority and therefore the legitimate production of knowledge in all aspects of social life (Han, 2015). The “"holy trinity' of Marx, Weber and Durkheim," are the most widely used of the classical social theorists (Shilling, 2011:2) and all three theorists had much to say about the role of religion in modern societies (Turner, 2014: 772).

Secularization became synonymous with modernization over the course of the twentieth century in Europe and elsewhere. According to O’Donnell (2009: 203) “The twenty-first century is often described as 'postmodern'." He goes on to state that postmodernism is an ideology stemming from after the Second World War that rejects the assumed certainties of the modern period:

Absolute truth is rejected and people find themselves swimming in a stream of evermoving ideas. Truth is a project, unfinished and in progress. Human beings cannot know everything or have an objective, God's-eye view. We have to live with contingency and humble limitations.

Moreover, Roger Trigg (2007:1) suggests today’s postmodern societies, particularly in North America and Europe, have become "pluralistic" in terms of containing a plethora different beliefs, all of which are diverse in their claims to truth even if they are at odds with one another - no belief is regarded as having pre-eminence over another.

The dominance of secularization and the celebration of pluralism in post-modern societies meant that for the second half of the twentieth century "religion has tended to be restricted to the private sphere" (Brewer, 2007: 9). The extent of this 'privatization' of religion varies between different nation-states. In France and the USA for instance, there is a separation between religion and politics or church and state in the constitution, whereas in the 
UK there has traditionally been a link between church and state with an established church, the Church of England (since the Reformation), recognised by the state. The USA and the UK have always allowed religious freedom and tolerance has traditionally been regarded a key societal value. Yet that is not currently the case in France where since 1905 the official secularity of the state termed 'Laïcité' has strictly precluded any religious involvement in government and vice versa. Moreover, during the time of the Soviet Union many nations under Soviet occupation were denied religious freedom under the totalitarian regime of Communism and official state atheism which completely denied the existence of God. In occupied countries the state and the ruling Communist Party were over bearing and severely restricted all forms of organized religion as they were seen as a threat to the authority of the state. During this time many Christians were persecuted, imprisoned, tortured and martyred for their faith and denied any religious freedom whatsoever. Since 1989 and the fall of the Berlin Wall, religion, and particularly Christianity, has re-emerged into public life in Eastern and Central Europe and it was in the early 1990s that the place of religion in the public sphere began to become a prominent and hotly debated issue (Casanova, 1994).

Turner (2014: 774-5) states that there has been a "revival of the sociology of religion in the late $20^{\text {th }}$ and early $21^{\text {st }}$ century" which is "associated with growing recognition of the importance of religion in public life". Moreover, the post-secularization thesis of the wellknown contemporary social theorist Jürgen Habermas (2006) argues that secular and religious citizens have a duty to engage in dialogue within the public sphere in the interests of reaching a liberal consensus on certain issues.

Jens Köhrsen (2012: 274) states that: "The public sphere can be defined as an open social arena in which a significant part of the population of a society participates passively or actively." This is made possible by the mass media. Köhrsen argues that the political public sphere is perhaps the most crucial and visible of all as it has the potential to impact upon the 
whole population. Davie (2015) suggests that the impact of religion in the public spheres of law, welfare, health care and politics have been discernible in relation to postmodern societies in the twenty-first century. As well as these, Trigg (2007) adds education as another public issue for debate.

A brief historiography of the topic of public religion will be outlined in the penultimate section of this essay. First, it is important to consider the global growth of Christianity amidst secularization.

\section{The Global Growth of Christianity in the Face of Secularization}

James Adair (2008: 317) writes that the period of the late twentieth and early twenty-first centuries has been regarded by some commentators as "the post-Christian era, because of the decreasing influence of the church on public life." A cursory glance at facts and figures drawn from recent surveys conducted in nation-states across Europe, it is clear to see that Christianity appears to be in decline. This is certainly what the main proponents of secularization have proposed. Despite advancing secularization, according to Peter Clarke (2009: 3), we are currently witnessing "renewed religious vitality" on a global scale. The sociologist Peter Berger (1999) argued that we began to witness the 'desecularization' of the world in the late $20^{\text {th }}$ century as there has been (and continues to be) a global resurgence in religious adherents.

In contrast to the assumed death or decline of Christianity in Europe, the number of Christians has paradoxically been expanding on a global scale since at least 1500 and at a particularly rapid rate since 1900 . Whilst space prevents a chronicling of the entire history of Christianity through the ages, it is useful to have a brief look at the expansion of Christianity since 1900. Threlfall-Holmes (2012: 129) states that Christianity has grown significantly, "from around 500 million adherents in 1900 to around 2 billion in 2000, nearly a third of the 
world's population." Despite secular claims that the Christian church in Britain is currently in decline, the contributions to Goodhew's (2012) edited text Church Growth in Britain: 1980 to the Present highlight clear signs of vitality and growth across many Christian denominations since the 1980s. Goodhew (2012: 3) writes that despite popular belief that Christianity in Britain is in decline, substantial and sustained church growth has also taken place across Britain over the last 30 years. This growth is large-scale; it is occurring across a wide geographical range; it is highly multi-cultural in its social reach; and it shows no sign of slowing down. The current consensus, by focusing almost exclusively on decline, is seriously mistaken.

An obvious example is the rapid growth of Pentecostalism which began in 1906 following the Azusa Street revival in Los Angeles. Jennings (2015: 62) argues that this "constitutes Christianity's most compelling response to secularisation theory." The Pentecostal church was birthed in the $20^{\text {th }}$ century yet has grown from "zero to half a billion - all in the midst of an era when religion was supposed to be in decline" (Ibid.).

World War II had a huge impact on Christianity in Europe in particular and fuelled the idea that faith was in decline (Adair, 2008: 315). Despite this, there were revivals of Christianity in Europe and elsewhere from the late 1940s that rendered the assumed secularization of society somewhat of a myth. For example, from 1949 the Baptist preacher Billy Graham began mass rallies in the USA that still continue to reach many nations across the world today through 'The Billy Graham Evangelistic Association' (BGEA) founded in 1950. In collaboration with local churches across various denominations, these meetings have been held in tents, stadia, on outdoor expanses and other large venues and have often been extended by weeks due to the mass numbers of people attending. According to Billy 
Graham's biography section of the BGEA (2015) official website, he has personally preached to nearly 215 million people in more than 185 countries/territories worldwide.

Whilst the holding of mass rallies was not a new idea and had been seen in previous revivals of the eighteenth and nineteenth centuries across Europe and the rest of the world through the likes of George Whitefield (1714-70) and John Wesley (1703-91) and his brother Charles (1707-88) who birthed the 'Methodist' movement, Billy Graham's evangelistic crusades were broadcast live on the radio and television and publically decried the notion of the inevitable secularization of postwar societies often advocated in many areas of public life. It was not just evangelical Christians like Billy Graham who sought to turn hearts and minds to faith in Jesus Christ amidst increasing secularization.

In 1974 the German Pentecostal evangelist Reinhard Bonnke began a movement called 'Christ for all Nations' (CfaN) in Africa where he and his family had moved to be missionaries in 1969. Again, with support from local churches across different denominations, CfaN's Gospel Campaigns steadily grew in size and went from being held in sports stadia in various cities across the African continent to being held in a tent that could fit 10,000 people to another that could fit 34,000, the latter appearing in the Guinness Book of Records as the largest tent ever made. The tents eventually became redundant as attendance figures at the gospel campaign meetings grew so that they had to be held in the open-air. From the 1990s it became common for these open-air events to comprise over a million people. According to the $\mathrm{CfaN}$ official website (CfaN, 2015), over 73 million people have recorded decisions to become Christians (on 'decision cards' handed to them at the events which are collected by the CfaN team and given to local churches to follow-up).

These are just two examples from many which act to illustrate that Christianity is not in decline today and continues to grow at a global scale. It is important to recognise that the growth of Christianity has not just been stimulated by Evangelical and Pentecostal Christians. 
What became known as the 'Charismatic Renewal' first entered the Roman Catholic Church in the 1960s eventually spreading to around 100 million Catholics in 120 countries (O’Donnell, 2009: 179-80).

Protestants from other "mainline denominations" were also significantly impacted by the charismatic renewal which has stimulated "greater ecumenical openness as barriers are broken down" between different Christian denominations and unity is encouraged (Ibid: 180). This greater unity and ecumenism amongst the Christian denominations has enhanced the success of attempts at evangelism and further enthused the growth of Christianity.

One example of an inter-denominational global success story that might be classed as an unintended consequence of the charismatic renewal of the 1960s is the 'Alpha Course' which is a basic introduction to Christianity originating from the Anglican parish of Holy Trinity Brompton (HTB) in central London, England (see Alpha, 2015). Alpha was started by Reverend Charles Marnham, a curate at HTB in 1977, as an introduction to the basic principles of the Christian faith for new Christians. Alpha grew rapidly in the UK throughout the 1990s after Nicky Gumbel, who practised as a barrister for ten years before becoming a vicar, took over the running of it at HTB in 1990 after realising the appeal of the course to those who would not normally attend church (Hocken, 2002: 312). At the time of writing the course continues to grow in popularity and has now run in 169 countries and in 112 languages (Alpha, 2015). Although originating in a church, the key to the success of the Alpha course is that it can be and has been conducted anywhere, including: prisons, universities, schools, colleges, homes, work places, coffee shops, public houses, bars and gyms/sports clubs.

It is also important to note that Christian revivals have occurred in an underground fashion amidst persecution and even under totalitarian regimes where all organized religion 
was severely restricted. Arguably the last great Christian revival in Europe, which reached hundreds of thousands of people, occurred (ironically) during the time of Soviet occupation. A $12^{\text {th }}$ century church called Olevista in Tallinn, the capital city of Estonia, witnessed hundreds of thousands of people from across the Soviet Union coming to faith in Christ and multitudes of miraculous healings in what has been termed "The Great Soviet Awakening" (Kraeuter, 2012).

These brief examples act to illustrate the trend of Christian growth amidst claims of advancing secularization and 'religious' decline in postmodern societies.

\section{Historiography}

Whether or not religious viewpoints should have a place in debates on public issues, particularly those in European and North American societies, has been a hotly debated subject generally revolving around the secularization debate over the decline of religion versus its resurgence. Considering the secularization debate is one of the largest debates within the study of contemporary religion, a brief outline of some of the main arguments relating to the topic of public religion are provided here.

Prior to the 1970 s the secularization thesis that dominated academic debate on religion was widely accepted and undisputed until Peter Berger (1967) predicted that religion would be pushed away from the public sphere and into the private sphere as a result of socioeconomic advancement in increasingly secular societies. Thomas Luckmann (1967) asserted that religion would not necessarily decline but it would become invisible from the public sphere and unrecognisable as modernity advanced. Bryan Wilson (1977) agreed that religion would cease to have impact in the public sphere and would increasingly be regarded as a matter of choice by the secular majority in society. Thus, the privatization thesis became a 
dominant argument in the study of religion and redefined the well-established secularization thesis by referring to an individual privatization of religion rather than outright decline.

José Casanova's (1994) seminal text Public Religions in the Modern World presented a challenge to the privatization thesis. Casanova's (1994: 5) central thesis was that "we are witnessing the de-privatization of religion" within which the private sphere becomes repoliticised and the spheres of economics and politics become re-normativized. He defined deprivatization as follows: "the fact that religious traditions throughout the world are refusing to accept the marginal and privatized role which theories of modernity as well as theories of secularization had reserved for them" (Ibid.). Thus Casanova refuted the notion that the privatization of religion was a necessity in modern societies arguing that religion has maintained a public role. The use of the term 'public religion' became widely used but has also faced criticism resulting in Casanova making a number of changes to his original thesis (see Casanova, 2003; 2006; 2008; 2009; 2011).

In later work, Berger (1999) refuted his privatization thesis arguing for the desecularization of society due to the rise in the number of religious adherent across various regions of the world. Jürgen Habermas $(2006 ; 2008)$ has been one of the most famous contributors to the debate on public religion. Habermas uses the term 'post-secular' to describe that state of contemporary societies within Europe, Australia, New Zealand and Canada and encourages the involvement of religious viewpoints in public affairs within such nations. In particular he argues that public debate on moral issues might benefit from input from religion. There are many other contributors to the debate on public religion but space impedes their coverage here. A number of useful overviews of this academic debate are available in sociology of religion textbooks. Shorter overviews are provided by Stark and Finke (2000: 57-79) and more recently by Robin Gill (2012a: 165-185) and Jens Köhrsen (2012). As well as providing a useful overview of arguments within the area of public 
religion, Köhrsen (2012: 274) argues that "the presence and importance of public religion in Western Europe are generally overstated" and that the impact of religion in the public sphere is in fact not rising.

In the USA, some alternatives to the secularization thesis that is dominant in debates regarding religion (and particularly Christianity) in Europe, have arisen, the most prominent being 'Rational Choice Theory' (RCT). Roger Finke and Rodney Stark (2005) have been the main proponents of this theory which has been largely based on American society (although the theory has been applied to other social contexts more recently). The RCT perspective suggests that the USA's religious terrain operates as a free market economy and human beings in American society use rational choice (weighing up benefits and costs) in order to determine how they make use of religion just like they would do when investing in other goods available in wider society. When religious options or supply are limited in terms of quality and diversity as they are in nation-states where there are established churches which hold some kind of monopoly on the religious marketplace (such as Germany); demand is also limited and this leads to religious decline. However, when there are competing suppliers of religion (as in more pluralistic nation-states like the USA), the supply of religious options is more diverse, of better quality, and thus more appealing resulting in religious vitality. This is regarded as a way of explaining the more dynamic and vibrant state of Christianity in the USA compared with much of Europe.

What is perhaps most interesting is that although the vast majority of contributors to this debate are from Europe and the USA, when it comes to the growth of Christianity globally it is non-Western nations that are leading the way and the future of Christianity is being determined by the remarkable expansion in the number of Christians in Africa, Asia and Latin America. In relation to this, in the third edition of his widely acclaimed The Next Christendom: the Coming of Global Christianity, Philip Jenkins (2012) asks the following 
key questions: How should we interpret the enormous success of prosperity churches across the Global South? Politically, what will be the impact of new Christian movements? Will Christianity contribute to liberating the poor, to give voices to the previously silent, or does it threaten only to bring new kinds of division and conflict? Does Christianity liberate women, or introduce new scriptural bases for subjection?

Global perspectives are vitally important due to the migration of people across national borders that has long been a theme of Christian mission and is now more possible than ever due to globalization and advances in global transport systems. Moreover, the secularization thesis and RCT do not work equally well in all national contexts and there are questions about their validity outside Europe and the USA.

There are a few academics who explicitly make a case for Christianity as public religion. Roger Trigg (Trigg, 2007: 3) argues that Christianity should have a place in public debate, mainly because of the historical fact that "the standards of Western society have arisen from a Christian background." Later, when discussing the link between Church and State in Europe and the USA, and specifically in relation to the established Anglican Church in England, Trigg (2007: 29) states: "If the roots of a respect for liberty, and for the valuing of toleration, are themselves nourished by the Christian tradition, then banishing that tradition from public influence could destroy the plant." Trigg asserts that one of the major problems in contemporary western societies is that there is an ignorance to the topic of religion. There is a tendency to lump all religions together rather than looking specifically at what the differences are between different faiths. This kind of reasoning neglects the contribution that Christianity can make to public life because it regards all religions as beyond the scope of reason (Ibid.: 33). Trigg takes exception to the notion that religion and rationality are separate and that secular reasoning and motivation are more neutral than religious reasoning and motivation. With reference to the motivations of past Christians, he writes: 
It is a part of civic virtue only to be motivated by secular reasons. Yet the idea that there is some deep mismatch between the pursuit of political equality in a democracy, and religion as a motive force is curious. The influence of religion may not always be beneficial, but it is undeniable that many social advances have been directly motivated by Christian belief. The campaign for the abolition of slavery in the British Empire at the beginning of the nineteenth century, and the American civil rights movement in the twentieth, were both examples of reforms brought about largely by those who were explicitly inspired by Christian belief in the love of God for all. (Trigg, 2007: 40)

In 2007, the former Archbishop of Canterbury, Rev Dr Rowan Williams, gave a lecture at St Andrew's Cathederal in Singapore in which he suggested why Christianity has a significant contribution to make to issues in the public sphere within modern democratic societies. In his speech he demonstrated a lucid understanding of the history of increasingly rational secular modern societies following the Enlightenment period and some of the negative consequences of the reliance on science and technological development above Christian values. The first of these principles is that God has created the world and every person in the world which means every person is unique and has a God-given calling and purpose. This value ascribed to every single human being motivates Christians to have reverence for others out of reverence for God rather than out of some legal entitlement to human rights: "the Christian gospel declares that there is nothing more Godlike and precious than a single human person" (Ibid.). Williams goes on to say the following:

These are ideas which people of many faiths can share and work on together in society. But there is an extra element brought by Christianity to the analysis of a good society, and this is the second point I want to underline. The New Testament 
describes what happens when human beings are brought into relationship with Jesus Christ by faith as a community in which everyone's gifts are set free for the service of others. The community that most perfectly represents what God wants to see in the human world is one where the resources of each person are offered for every other, whether those resources are financial or spiritual or intellectual or administrative. This is the pattern of the Body of Christ as St Paul defines it. It is not only that the least and apparently most useless still has the dignity of having a gift and a purpose; it's also that everyone is able to give to others, to have the dignity of being a giver, being important to someone else. Instead of just a static picture of everyone having dignity, the Christian vision is dynamic - everyone engaged in building up everyone else's human life and dignity. (Ibid.)

Summarizing his views on the contribution of Christianity to public affairs, Williams states the following:

It is not that the state and the laws of society must represent in all respects the commands of the gospel; it is rather that the state will become a sterile and oppressive thing unless it is continually engaged in conversation with those who speak for the gospel. That is perhaps the essence of the Christian contribution in the public sphere. It is a voice that questions from a wholly different perspective, the kind of perspective that cannot be generated by corporate self-interest. It is a conversation partner, and what has sometimes been called a critical friend to the state and its laws; it asks about the foundations of what the state takes for granted and often challenges the shallowness of a prevailing social morality; it pushes for change to make the state a little more like the community that it is itself representing, the Kingdom of God. It does not make the mistake of talking as though politics would bring the Kingdom into 
being on earth, but it continually seeks to make the promise of the Kingdom more concrete and visible in the common life of human beings, private and public. In short, it tells the state not that it is unimportant or subordinate to some higher earthly power, but just that it is relative in the perspective of God. If a certain degree of shared humility and realism is part of the life of a healthy state and society that is one of the things that Christian proclamation can offer. (Ibid.)

In this seemingly post-secular age, many questions remain regarding the precise contribution Christianity can make to debates within the public sphere. There are still disagreements over whether the Christian gospel message should legitimately have an impact on decision-making on political issues at all. The amount of books, journal articles and web resources on the topic of public religion are still increasing which highlights that this issue is far from being resolved and perhaps never truly will be. There are a lack of explicitly religious contributors to the debate on this topic both within and outside academia and the area still remains dominated by secular thinkers. This is where the contributions of figures such as Rowan Williams to the debate regarding the importance of Christianity to public life matter, and is why his viewpoints have been quoted at length above. If the Christian gospel message is no longer considered relevant and important to public affairs then answers to the many problems that arise in society will continue to be one-sided. If the Christian gospel is ignored and not considered a legitimate moral compass that should not be voiced in public because it is considered a belief rather than a fact, then surely the same should be said for secular or atheistic beliefs. Yet the latter have been put forward above the former and Christianity has been lumped together with other 'religious' viewpoints that are increasingly pushed behind the scenes of public life despite, in the case of Christianity at least, being at the very heart of the value system upon which Western democracy was founded. This is the fundamental reason for why Christianity should be public. 


\section{Primary Sources}

For further evidence that the Christian gospel message was intended to be public, the New Testament (Holy Bible) should be the first port of call. In particular the first five books of the New Testament: the four Gospels - Matthew, Mark, Luke and John - and the fifth book, Acts of the Apostles. A thorough grounding in theology is not required in order to read the bible to discern this information and a vast number of bible study guides, commentaries, encyclopaedias and dictionaries are available both in print and online. A highly accessible online resource that pools many of these types of sources together in one place is 'Bible Gateway'.

There are many useful texts that provide a broad overview of the 2000 year history of Christianity which it has not been possible to cover in this essay due to space. A few recent examples of easily accessible and very readable titles include: James Adair's (2008) Introducing Christianity; Kevin O'Donnell's A Pocket Guide to Christian History; and, Miranda Threlfall-Holmes' (2012) The Essential History of Christianity.

There are an increasing number of research agencies and think tanks that focus on the place of religion in the public sphere that make their primary research and that of others readily available via the Internet. Empirical research coordinated and led by these bodies often informs what the media say about the place of religion in the public sphere in many societies. One example of a global think tank based in the USA is Patheos Patheos.com. Similarly, the Religion \& Public Life section of the Pew Research Center is a US based "nonpartisan" fact tank. There are also other research organisations based on understanding the role of religion in the public sphere in the USA, including the Public Religion Research Institute (PRRI). One of the main Christian think tanks working in the area of religion, politics and society in Britain is Theos who "aim to inform debate around questions of faith 
and secularism and the related subjects of values and identity". Theos was launched in 2006 and their first report was on the reasons why faith will play an increasingly significant role in public life (Spencer, 2006). Another Christian organisation who aim to connect religious with secular thinkers is the William Temple Foundation which has existed since 1947. Seeking to enhance a Christian perspective using market research, is a group called Christian Research. Regarding public policy debates on religion in Britain, Public Spirit is an online forum for sharing information between various individuals and groups. British Religion in Numbers (BRIN) is an example of an online religious data resource. The welcome page of their website states the following about the kind of research questions they ask and the issues on which they seek to gather data. There are also a number of research initiatives and collaborations occurring across various universities in the USA and Europe. For example, the

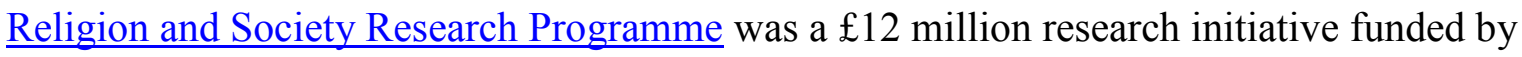
two UK research councils Arts and Humanities Research Council (AHRC) and Economic and Social Research Council (ESRC) and Lancaster University. A total of 75 projects were funded at universities across the UK to conduct research on the interrelationships between religion and society. This research informed the Westminster Faith Debates between 2012 and 2015 which were public debates regarding the place of religion in society.

A slightly different example is The Impact of Religion research programme based in the Religion and Society Research Centre at Uppsala University in Sweden, which aims to study, "the place of religion in society in the light of complex economic, social, political, legal and cultural transformations taking place in Sweden and the Nordic countries." An example of research based at an American university is Rice University's Religion and Public $\underline{\text { Life }}$ research programme based in the Social Science Research Institute, which aims to "shape understanding of the role of religion in public life today." 
It is important for the reader to note that this is not an exhaustive list of all the primary resources on the topic but hopefully it provides some useful examples to demonstrate what is readily available.

\section{Further Reading}

Adair, James A. (2008) Introducing Christianity. New York: Routledge.

Berger, Peter Ludwig (1967) The Sacred Canopy: Elements of a Sociological Theory of Religion. New York: Doubleday.

Berger, Peter Ludwig (1999) Ed. The Desecularization of the World: Resurgent Religion and World Politics. Grand Rapids, Michigan: W.B. Eerdmans.

Berg-Sørensen, Anders (2013) Ed. Contesting Secularism: Comparative Perspectives. Farnham: Ashgate.

Burgess, Stanley M. and van der Maas, Eduard M. (2002) Eds. The New International Dictionary of Pentecostal and Charismatic Movements. Grand Rapids, Michigan: Zondervan. Butler, Judith, Habermas, Jürgen, Taylor, Charles and West, Cornel (2011) The Power of Religion in the Public Sphere. New York: Columbia Press.

Campolo, Tony (1995) Partly Right: Learning from the Critics of Christianity. Dallas, Texas: Word Publishing.

Casanova, José (1994) Public Religions in the Modern World. Chicago, Illinois: University of Chicago Press.

Dinham, Adam and Francis, Matthew (2015) Eds. Religious Literacy in Policy and Practice. Bristol: Policy Press.

Fraser, David A. and Campolo, Tony (1992) Sociology Through the Eyes of Faith. New York: Harper Collins. 
Goodhew, David (2012) Ed. Church Growth in Britain: 1980 to the Present. Surrey:

Ashgate.

Habermas, Jürgen (2006) "Religion in the public sphere.” European Journal of Philosophy $14(1): 1-25$.

Habermas, Jürgen (2008) "Notes on post-secular society.” New Perspectives Quarterly 25 (4): 17-29.

Hjelm, Titus (2015) Ed. Is God Back? Reconsidering the New Visibility of Religion. London: Bloomsbury.

Holy Bible, New International Version.

Hunter, James Davison (2010) To Change the World: The Irony, Tragedy, \& Possibility of Christianity in the Late Modern World. New York: Oxford University Press.

Köhrsen, Jens (2012) "How religious is the public sphere? A critical stance on the debate about public religion and post-secularity." Acta Sociologica 55 (3): 273-288.

Luckmann, Thomas (1967) The Invisible Religion: The Problem of Religion in Modern Society. New York: MacMillan.

Martin, David (2011) The Future of Christianity: Reflections on Violence and Democracy, Religion and Secularization. Farnham: Ashgate.

Meyer, Birgit and Moors, Annelies (2006) Eds. Religion, Media, and the Public Sphere. Bloomington, Indiana: Indiana University Press.

Mouzelis, Nicos (2012) “Modernity and the Secularization Debate.” Sociology 46 (2): 207223.

O’Donnell, Kevin (2009) A Pocket Guide to Christian History. Oxford: Lion Hudson. Threlfall-Holmes, Miranda (2012) The Essential History of Christianity. London: SPCK publishing. 
Trigg, Roger (2007) Religion in Public Life: Must Faith be Privatized? Oxford: Oxford University Press.

Williams, Rowan (2007) “Christianity: Public Religion and the Common Good.” Available at:

http://rowanwilliams.archbishopofcanterbury.org/articles.php/1165/christianity-publicreligion-and-the-common-good (Accessed June 2015).

\section{References}

Adair, James A. (2008) Introducing Christianity. New York: Routledge.

Alpha (2015) “About Alpha.” Alpha International Official Website. Available at:

http://uk.alpha.org/about (Accessed July 2015).

Berger, Peter Ludwig (1999) "The Desecularization of the World: A Global Overview." The

Desecularization of the World: Resurgent Religion and World Politics. Ed. Peter Ludwig

Berger. Grand Rapids, Michigan: W.B. Eerdmans: 1-18.

Brewer, John David (2007) "Sociology and theology reconsidered: religious sociology and the sociology of religion in Britain.” History of the Human Sciences 20 (2): 7-28.

BGEA (2015) “Billy Graham.” Billy Graham Evangelistic Association Official Website.

Available at: http://billygraham.org/about/biographies/billy-graham/ (Accessed July 2015).

Casanova, José (1994) Public Religions in the Modern World. Chicago, Illinois: University of Chicago Press.

Casanova, José (2003) "Beyond European and American exceptionalisms: Towards a global perspective." Predicting Religion: Christian, Secular, and Alternative Futures. Eds. Grace

Davie, Paul Heelas and Linda Woodhead. Farnham: Ashgate: 17-29.

Casanova, José (2006) Rethinking secularization: A global comparative perspective.

Hedgehog Review 8 (1-2): 7-22. 
Casanova, José (2008) “Public Religions revisited." Religion: Beyond a Concept. Ed. Hent de Vries. New York: Fordham University Press: 101-119.

Casanova, José (2009) “The religious situation in Europe.” Secularization and the World Religions. Eds. Hans Joas and Klaus Wiegandt (trans. Alex Skinner). Liverpool: Liverpool University Press: 206-227.

Casanova, José (2011) "Cosmopolitanism, the clash of civilizations and multiple Modernities.” Current Sociology 59 (2): 252-267.

CfaN (2015) “The history of Christ for all Nations." Christ for all Nations Official Website. Available at: http://www.cfan.org.uk/about/history-christ-all-nations (Accessed July 2015). Clarke, Peter (2009) “Introduction: Towards a More Organic Understanding of Religion within a Global Framework." The Oxford Handbook of the Sociology of Religion. Ed. Peter Clarke. Oxford: Oxford University Press: 1-27.

Gill, Robin (2012a) Theology in a Social Context: Sociological Theology (Volume 1). Surrey: Ashgate.

Goodhew, David (2012) "Church Growth in Britain, 1980 to the Present Day." Church Growth in Britain: 1980 to the Present. Ed. David Goodhew. Surrey: Ashgate: 3-20. Finke, Roger and Stark, Rodney (2005) The Churching of America, 1776-2005: Winners and Losers in Our Religious Economy. New Jersey: Rutgers University Press.

Fraser, David A. and Campolo, Tony (1992) Sociology Through the Eyes of Faith. New York: Harper Collins.

Habermas, Jürgen (2006) "Religion in the public sphere.” European Journal of Philosophy $14(1): 1-25$.

Habermas, Jürgen (2008) “Notes on post-secular society.” New Perspectives Quarterly 25 (4): 17-29. 
Han, Sam (2015) 'Disenchantment revisited: Formations of the 'secular' and 'religious' in the technological discourse of modernity." Social Compass 62 (1): 76-88.

Hocken, Peter D. (2002) “Alpha Course.” The New International Dictionary of Pentecostal and Charismatic Movements. Eds. Stanley M. Burgess and Eduard M. van der Maas. Grand Rapids, Michigan: Zondervan: 312.

Jenkins, Philip (2012) The Next Christendom: The Coming of Global Christianity (Third Edition). Oxford: Oxford University Press.

Jennings, Mark (2015) “An extraordinary degree of exaltation: Durkheim, effervescence and Pentecostalism's defeat of secularisation.” Social Compass 62 (1): 61-75.

Köhrsen, Jens (2012) "How religious is the public sphere? A critical stance on the debate about public religion and post-secularity." Acta Sociologica 55 (3): 273-288.

Kraeuter, Tom (2012) The Great Soviet Awakening: The True Story the West Was Never Told. Hillsboro, Missouri: Training Resources, Inc.

Mouzelis, Nicos (2012) “Modernity and the Secularization Debate.” Sociology 46 (2): 207223.

O’Donnell, Kevin (2009) A Pocket Guide to Christian History. Oxford: Lion Hudson. Shilling, Christopher (2011) “Series Editor's Introduction.” The Sociological Review 59 (s1): $1-4$.

Spencer, Nick (2006) ““"Doing God”: A Future for Faith in the Public Square.” Theos. Available at: http://www.religionlaw.co.uk/TheosDoingGod.pdf (Accessed July 2015). Stark, Rodney and Finke, Roger (2000) Acts of Faith: Explaining the Human Side of Religion. California: University of California Press.

Threlfall-Holmes, Miranda (2012) The Essential History of Christianity. London: SPCK publishing. 
Trigg, Roger (2007) Religion in Public Life: Must Faith be Privatized? Oxford: Oxford University Press.

Turner, Bryan Stanley (2014) "Religion and contemporary sociological theories." Current Sociology Review 62 (6): 771-788.

Williams, Rowan (2007) “Christianity: Public Religion and the Common Good.” Available at:

http://rowanwilliams.archbishopofcanterbury.org/articles.php/1165/christianity-publicreligion-and-the-common-good (Accessed June 2015).

Wilson, Bryan Ronald (1977) “How religious are we?” New Society 42: 176-178.

Wilson, Bryan Ronald (1998) "The secularization thesis: Criticisms and rebuttals".

Secularization and Social Integration: Papers in honor of Karel Dobbelaere. Eds. Rudy Laermans, Bryan Ronald Wilson and Jaak Billiet. Leuven: Leuven University Press: 45-66. 